\title{
The evolution of the doctrine of consent
}

\author{
Peter Marks
}

\begin{abstract}
The doctrine of informed consent is evolving. It has taken different routes in different jurisdictions. However, these different paths are converging to a general consensus. The Bolam test, which has been the primary exposition of this doctrine in this country, sets the standard of care as a matter of medical judgement. However, recent cases, particularly Rogers $\mathrm{v}$ Whitaker, shift the perspective in favour of warning the patient of material risks inherent to proposed treatment. Whether this information is sufficient to give consent is not a question the answer to which depends upon standards of medical practice. There is no doubt that this is the evolving global trend. Whilst this might seem more onerous the doctrine is of constructive use in securing public awareness in organ donation and in the effectiveness of public health policies.
\end{abstract}

KEY WORDS: informed consent, ethics, medical negligence, organ transplant, Bolam, donor

\section{The history}

It is a mistake to view a continuum as a single event. The evolving phenomenon that is known as informed consent is a montage of perception and the changing balance of power between patient and doctor. This entered the English law via the decision of the Supreme Court of Canada in Reibl v. Hughes [1980 $]^{1}$ which held that the 'duty to warn' arises from the 'patient's right to know of material risks, a right which in turn arises from the patient's right to decide for himself or herself whether or not to submit to the medical treatment proposed'. This is echoed in the expressions used in American authorities such as 'the patient's right of self-determination', as used in the case of Canterbury v. Spence [1972] . ${ }^{2}$ The English law took the same view but differently and later. The Bolam principle derived from the direction given by McNair J to the jury in the case of Bolam v. Friern Hospital Management Committee [1957]. ${ }^{3}$ In Sidaway v. Governors of Bethlem Royal Hospital [1985], ${ }^{4}$ Lord Scaman stated the Bolam principle in these terms:

The Bolam principle may be formulated as a rule that a doctor is not negligent if he acts in accordance with a practice accepted at the time as proper by a responsible body of medical opinion even though other doctors adopt a different practice. In short, the law imposes the duty of care: but the standard of care is a matter of medical judgement. ${ }^{4}$

\section{The current perspective}

Whilst no single word or sentence can encapsulate the wisdom of practice of a profession, some can, by their aura of immunity, escape or at least not discharge that which they should prevent. It thus has remained for the landmark judgement of Rogers v. Whitaker $[1992]^{5}$ to express what has been a source of major controversy. The facts are simple but tragic. Marie Whitaker who had been almost totally blind in her right eye, contacted Christopher Rogers; an ophthalmic surgeon, who advised her that an operation on that eye would not only improve its appearance but would probably restore significant sight to it. She agreed to undergo surgery. After the operation there was no improvement to the right eye, and Whitaker developed inflammation in the left eye which led to loss of all sight in that eye. She sued Rogers in the Supreme Court of New South Wales for damages in negligence. Campbell $\mathrm{J}$ found Rogers liable in that he had failed to warn Whitaker that, as a result of the surgery, she might develop a condition known as sympathetic ophthalmia in her left eye.

In the case it was said that nothing is to be gained by reiterating the oft used and somewhat amorphous phrase 'informed consent'. The judgement is explicit. Simplicity has no need of sophistry to distract. The words express without embellishment the public fear of complete autonomy. One must expect a change although this is a change that has already happened. Looking forward to the past of Canterbury v. Spence [1972] it advised:

Except in the case of an emergency or where disclosure would prove damaging to the patient, a medical practitioner has a duty to warn the patient of a material risk inherent in proposed treatment. A risk is material if, in the circumstances of the particular case, a reasonable person in the patient's position, if warned of the risk, would be likely to attach significance to it or if the medical practitioner is or should reasonably be aware that the particular patient, if warned of the risk, would be likely to attach significance to it. The fact that a body of reputable medical
Peter Marks MB MSC LLB MRCP MA DCH, Barrister-at-Law 
practitioners would have given the same advice as the medical practitioner gave does not preclude a finding of negligence. Generally speaking, whether the patient has been given all the relevant information to choose between undergoing and not undergoing the proposed treatment is not a question the answer to which depends upon medical standards or practice. ${ }^{2}$

\section{The recent past}

Rogers v Whitaker echoes the sentiments of the earlier case $F$ v. $R$ $[1983]^{6}$ which was decided by the Full Court of the Supreme Court of South Australia two years before Sidaway in the House of Lords. A woman who had become pregnant after an unsuccessful tubal ligation brought an action in negligence alleging failure by the medical practitioner to warn her of the failure rate of the procedure. The failure rate was assessed at less than $1 \%$ for that particular form of sterilisation. The court refused to apply the Bolam principle. King CJ said:

The ultimate question, however, is not whether the defendant's conduct accords with the practices of his profession or some part of it, but whether it conforms to the standard of reasonable care demanded by the law. That is a question for the court and the duty of deciding it cannot be delegated to any profession or group in the community. ${ }^{6}$

$F$ v. $R$ anticipates the later judgements in Smith v. Tunbridge Wells Health Authority [1994]. ${ }^{7}$ Medical opinion must be 'reasonable or responsible' and not to mention the risk of impotence from rectal surgery is not so. It was also held that if the risk of impotence had been explained to the plaintiff he would have refused the operation. The judgement paraphrases the anticipatory wisdom of Canterbury v. Spence [1972]. Information is equated with consent and consent with respect.

One has here the excellent example of different jurisdictions reaching the same destinations at different times and by different routes. Looking back for the future one sees the ethics clearly articulated in Canterbury v. Spence. In its detail it anticipates the future developments:

- Every human being, and thus every medical patient of adult years and sound mind has the right to determine what shall be done with his own body.

- The physician is under a duty to treat his patients skilfully, but proficiency in diagnosis and therapy is not a full measure of his responsibility.

- It is the prerogative of the patient, not the physician, to determine for himself the direction in which his interests seem to lie.

- The physician cannot ordinarily obtain verbal consent from the patient for therapy without first elucidating options and perils for the patient's edification.

- The physician's duty to inform the patient is not dependent upon the patient's request for disclosure. ${ }^{2}$

These are expressions of archetypal wisdom and different jurisdictions have moved towards embracing this philosophy. Those that have moved slowest have had problems which could have been prevented. Those that have only pretended to move will have the greatest difficulty.

\section{The German experience}

There is considerable difference between the laws governing involuntary admission to hospital and treatment under Mental Health Law in the United Kingdom and Germany. Whereas British law gives key powers to multi-professional decision making and relatives, German law requests formal Court decisions even in routine issues. This reflects a different understanding of individual rights and their protection. The German mental health law is motivated by the experiences of the totalitarian National Socialist regime. It tries to protect the patients' rights by restricting physicians, hospitals and family members' influence. British law, on the other hand, assumes that experts as well as family members act benevolently in the patient's interest and prefers less formal mechanisms and expresses trust in professional ethics. ${ }^{8}$

In the Federal Republic of Germany there is no regulation which can be invoked to supervise a patient against his will after discharge from hospital. This is the freedom to be ill which is estimated within the 'Freiheit Zum Krankstein' (BVerfGE 58,208 226ff; 1998 erneut in 2 BuR 2270 (96)). Again the convergence of European medicolegal jurisprudence will need to reconcile these different approaches. This reconciliation will take more than time.

\section{The applications}

It is a mistake to view consent as a burden or hurdle that has to be vaulted rather than a standard of communicatory excellence to which we ought to aspire. The doctrine of presumed consent is an attempt to increase the number of organ donors. A presumption is a rule of law which provides that if a party proves a certain fact, known as the primary fact, then another fact, the presumed fact, will also be taken to be proved, unless evidence is adduced by the opponent to 'rebut' the presumption or, in other words contradict the presumed fact. Several examples have entered everyday usage. A person who has not been heard of for seven years by those who, if he had been alive would be likely to have heard of him, is presumed to be dead.

A presumption is the mechanism by which society encapsulates its wisdom. This is so with the presumption of innocence. The burden of proof is always cast upon the party asserting criminality.

The Organ Donation (Presumed Consent and Safeguards) Bill $^{9}$ was introduced by Labour backbencher, Tom Watson, under the ten-minute rule. The bill would introduce an opt-out, rather than an opt-in, system of organ donation after death, so everyone would be a potential donor unless they registered otherwise. This was an attempt to help the 7,000 people in the United Kingdom who are awaiting transplants. It is worthwhile, reinforcing the excellent first organ donation campaign aimed at African-Caribbeans. This is truly praiseworthy since the adverts give sufficient information to inform the reader of the scope of 
the problem and its solution, yet are sufficiently brief to be assimilated by a reader quickly passing. This is the dilemma in public health and ethics. Too little might alienate and patronise, too much might overwhelm.

\section{The future}

As medicolegal issues converge, particularly in Europe, the different approaches of different jurisdictions need to be analysed to aid convergence. This convergence is already part of the analysis of our educated public assessing its needs and the mechanism of supply of these needs. As the doctrine of informed consent evolves, as it will, so increasingly it will become synonymous with the sharing of information. This is not defensive medicine. Medicine without consent or this sharing of information is offensive medicine. Medicine with shared information is effective medicine.

\section{References}

Reibl v. Hughes [1980] 2 SCR 880, 1980114 DLR (3d).

Canterbury v. Spence (1972) 464 F2d 772.

Bolam v. Friern Hospital Management Committee [1957] 1WLR 582: [1957] 2 All ER 118.

Sidaway v. Governors of Bethlem Royal Hospital [1985] AC 871.

Rogers v. Whitaker [1992] CLR 479-484.

Smith v. Tunbridge Wells Health Authority (1994) 5 Med LR 34.

8 Rottgers HR, Lepping P. Zwangsunterbringung und - behandlung psychisch Kranker in Großbritannien und Deutschland. Psychiatr Prax 1999:2b;139-142.

9 Organ donation (presumed consent and safeguards) (No 2) bill. July HCB 169 01/02 0215701526. 